\title{
Anti-Escherichia coli effect of Hibiscus sabdariffa L. in a meat model
}

\author{
Marcelo Pinto PAIM ${ }^{1}$, Mônica Jachetti MACIEL ${ }^{1,2 *}$, Simone WESCHENFELDER ${ }^{3}$, \\ Guiomar Pedro BERGMANN ${ }^{4}$, César Augusto Marchionatti AVANCINI ${ }^{1}$
}

\begin{abstract}
Hibiscus sabdariffa L. is used in traditional medicine because of its bioactive properties, such as antioxidant and antibacterial. Escherichia coli is a Gram-negative bacteria and as an indicator of contamination in food. The aim of this work was to evaluate the anti-Escherichia coli effect and the change in $\mathrm{pH}$ on the control of aerobic mesophilic microorganisms, using hydroethanolic extract of $H$. sabdariffa L. in different concentrations in a meat model, verifying its potential as food additive for microbiological stability on ground beef during cooling storage. For the preparation of the treatments, the meat experimental units were elaborated with different concentrations of the vegetal extract (5, 10, 15 and 20\%), ground beef and contaminated with $E$. coli. For $\mathrm{pH}$ evaluation, the meat experimental units were added different percentages of hydroethanolic extract. The $H$. sabdariffa L. antibacterial action reduced two logarithmic levels in practically all treatments. The best $\mathrm{pH}$ result was obtained in the meat containing $30 \%$ of the extract. The hydroethanolic extracts of Hibiscus sabdariffa L. showed anti-Escherichia coli activity in the presence of refrigerated ground beef. Analyzing the $\mathrm{pH}$ results and the count of aerobic mesophilic bacteria, it is possible this extract to be used as a natural food additive.
\end{abstract}

Keywords: antibacterial activity; ground beef; vegetable extracts.

Practical Application: Both synthetic chemical preservatives, as conventional, which has natural origin, has been questioned by causing health problems, and in this way, the search for healthy products increased. Although it seeks to develop new technologies for food preservation. The results obtained in this study, which was designed as applied research, indicated the potential of Hibiscus sabdariffa L. extractions as a food preservative, in order to maintain the ground beef microbiological stability under cooling, during storage. This result allows the development of another investigation phase, now with the objective of evaluating the meet tastefully preparations, having the plant extract as an additive.

\section{Introduction}

Hibiscus sabdariffa L. belonging to the Malvaceae family, which has over 200 genera and about 2300 plant species. This plant has probably an African origin, but is also cultivated in India and other parts of Asia, America and Australia, and was possibly introduced into Brazil by slaves. It is known by the name "hibiscus" and in some Brazilian states as well as "quiabo", "azedinha", "caruru" (MG), "groselha" (BA) and "vinagreira" (PA, CE, ES) (Esteves et al., 2014). Hibiscus sabdariffa L. is commonly used in traditional medicine because it has bioactive properties such as antitumor, anti-inflammatory, antioxidant, and antibacterial (Mehdi et al., 2013).

Escherichia coli are a Gram-negative bacteria, part of the Enterobacteriaceae group. It has a $\mathrm{pH}$ close to neutral, which provides an optimal condition for its development. The E. coli pathogenic strains are divided according to clinical symptoms and pathogenic mechanisms (Forsythe, 2013). According to studies carried out in different Brazilian cities and regions, there are high levels of contamination in ground beef (Nascimento et al.,
2014). These authors also pointed out the precarious conditions in which this product is offered to consumers.

Food additive is defined as any ingredient intentionally added to food without nurturing purpose, in order to modify the physical, chemical, biological or sensorial characteristics, during the manufacture, processing, preparation, treatment, packaging, wrapping, storage, transport or handling of food. The additives aggregated to the food may result in the additive itself or its derivatives converting into a component of the food (Brasil, 2000).

Food preservation methods are based not only on the reduction of the intensity action of deteriorating elements, but also on the modification or elimination of the conditions for microbiological life, making the substrate an inadequate medium to microorganisms (Silva, 2005; Nespolo et al., 2015). The use of acidification in food preservation is a very effective method, since the major foodborne pathogens grow mainly at neutral $\mathrm{pH}$. The acid stress is a combined effect of organic acids and low 
$\mathrm{pH}$. This preservative solution, which depends on $\mathrm{pH}$, causes the reduction of partial or total proliferation of the bacterial cells (Forsythe, 2013).

According to Freire (2004), the use of substances present in natural additives in food processing is admissible for purposes of conservation in burgers, meatballs, sausages, and dried and marinated meats, which have been studied in several researches using meat matrices (Simões et al., 2001; Mariutti et al., 2008).

With synthetic chemical preservatives being questioned to cause health problems or even because it increases the demand for healthy products, wanted (buscou-se) to develop new technologies for food preservation. Therefore, the aim of this work was to evaluate the anti-Escherichia coli and the change in $\mathrm{pH}$ effects of the hydroethanolic extract of $H$. sabdariffa on controlling aerobic mesophilic microorganisms, in different proportions in a meat model, in order to use it as a food additive for microbiological stability of ground beef during cooling storage. With synthetic chemical preservatives being questioned to cause health problems or even because it increases the demand for healthy products, we sought to develop new technologies for food preservation. Therefore, the aim of this work was to evaluate the anti-Escherichia coli and the change in $\mathrm{pH}$ effects of the hydroethanolic extract of $H$. sabdariffa on controlling aerobic mesophilic microorganisms, in different proportions in a meat model, in order to use it as a food additive for microbiological stability of ground beef during cooling storage.

\section{Material and methods}

The material for this study consisted of flower calyx samples of $H$. sabdariffa from the 2013/2014 crop season, acquired in the Ecologists Farmers Fair (FAE) in Porto Alegre, RS, Brazil, which was grown under an organic system. The exsiccatae were sent to the herbarium of the Botany Department, Biology Institute, Rio Grande do Sul Federal University (UFRGS), for registration, receiving the record ICN 165039.

The experiments were conducted in the laboratory of the Learning, Research and Meat Technology Centre (CEPETEC), Faculty of Veterinary Medicine and in the Institute of Sciences and Food Technology (ICTA), both from the Rio Grande do Sul Federal University (UFRGS), Porto Alegre, RS.

Extractions were performed using sepals dried at $40^{\circ} \mathrm{C}$. Ethyl (grain) alcohol (FARMAQUÍMICA SA ${ }^{\circledR} \mathrm{BR}$ ) at $70^{\circ} \mathrm{GL}$ was used for hydroalcoholic maceration, at $100 \mathrm{~g}$ of dried sepals per $1000 \mathrm{~mL}$ of alcohol. After at least fifteen days of maceration, the macerated sepals were filtered at room temperature, protected from light, and subjected to distillation under reduced pressure at $60^{\circ} \mathrm{C}$, using a rotary evaporator system (FISATON ${ }^{\circledR}$, model 802D). The alcoholic part was discarded, obtaining the hydroethanolic extract, according to the criteria of the Farmacopéia Brasileira (1987).

The ground beef sample was acquired as a consumer, in a shop in Porto Alegre, RS. The bacterial inoculum Escherichia coli (ATCC 11229) was prepared at densities of $10^{4}$ to $10^{8}$ colony-forming units CFU.mL ${ }^{-1}$ according to Barbosa et al. (2009) and used for inoculate the meat sample. Meat experimental units have been elaborated in different concentrations of the plant extract $(5,10,15$ and 20\%) and later contaminated with the bacterial inoculum. The experimental units weighed $200 \mathrm{~g}$, consisting of $5 \%$ hydroethanolic treatment $\left(\mathrm{HT}_{5 \%}\right): 180 \mathrm{~g}$ of ground beef, $10 \mathrm{~mL}$ of $5 \%$ hydroethanolic extract and $10 \mathrm{~mL}$ of each bacterial inoculum population density (Escherichia coli). It occurred in the same way with other treatments, $\mathrm{HT}_{10 \%}, \mathrm{HT}_{15 \%}$ and $\mathrm{HT}_{20 \%}$, only differentiating the percentage of extract. In an initial E. coli population densities of $10^{4}$ a $10^{8} \mathrm{CFU} \cdot \mathrm{mL}^{-1}$.

The treatments were homogenized and placed separately in glass vials for 24 hours at temperatures between $6{ }^{\circ} \mathrm{C}$ and $8{ }^{\circ} \mathrm{C}$. The methodology used for $E$. coli detection was according to Brasil (2003) with modifications. The E. coli quantification was performed using the cultural medium Chromocult Coliform Agar (MERCK ${ }^{\circledR} \mathrm{BRA}$ ) and incubated at a temperature of $36^{\circ} \mathrm{C} \pm 1^{\circ} \mathrm{C}$ for 24 hours. For the time being, according to Brasil (2003), the culture medium used to isolate total and thermotolerant coliforms is the Crystal Violet Neutral Red Bile agar (VRBA).

In order to study the $E$. coli lifetime, the treatments were constituted of the extract concentrations added to the meat samples: T0 - control without added the extract; T1 - $20 \%$ of the hydroethanolic extract and T2 - 30\% of the hydroethanolic extract. The meat from each treatment was placed in glass vials and manually homogenized for 2 minutes, totaling 3 bottles of $200 \mathrm{~g}$. These treatments were evaluated after $0,1,2,3,6$ and 9 days at a temperature of $7{ }^{\circ} \mathrm{C} \pm 1^{\circ} \mathrm{C}$, measuring their $\mathrm{pH}$ values and counting their mesophilic aerobic microorganisms. The $\mathrm{pH}$ was determined according to the methodology described by Association of Official Analytical Chemists (2012) and the counting of aerobic mesophilic microorganisms were performed using the methodology according to Brasil (2003).

\section{Results and discussion}

The results of the antibacterial action of the hydroethanolic extract of $H$. sabdariffa on the E. coli in the different treatments regarding the population densities in the meat samples are presented in Table 1. The H. sabdariffa L. extracts on the E. coli shown was infectious dose-dependent ( $p>0.05)$, however, the antibacterial action decreased two logarithmic levels in almost all treatments from the initial infecting doses. We have to emphasize that high pathogenic infective doses $\left(\geq 10^{6} \mathrm{CFUg}\right)$ are difficult to be normally found in food, without the organoleptic characteristics being compromised by the action of microorganisms (Silva, 2005). According to Germano \& Germano (2011), the high levels of fecal coliforms is not necessarily an indicative of diseases, which would require doses over $10^{5} \mathrm{CFU} \cdot \mathrm{g}^{-1}$ to cause physiological changes, depending on the intrinsic conditions of food and environmental factors. However, it is considered a relevant health indicator, demonstrating fecal contamination, hygiene unsatisfactory practices and possible presence of pathogenic microorganisms in food. Regarding the E. coli quantity, the extract action efficacy on $10^{6} \mathrm{CFU} . \mathrm{g}^{-1}(\mathrm{p}>0.05)$ was observed in all the treatments, reducing the microbiological limit to $10^{4} \mathrm{CFU} . \mathrm{g}^{-1}$, showing a constant homogeneity of the antibacterial action. 
Table 1. Antibacterial activity of the hydroethanolic extract of Hibiscus sabdariffa L. in a meat model experimentally front four treatments (HT ${ }_{5 \%}$, $\mathrm{HT}_{10 \%}, \mathrm{HT}_{15 \%}$ and $\mathrm{HT}_{20 \%}$ ) contaminated with different infective doses $\left(10^{4}\right.$ to $\left.10^{8} \mathrm{UFC}^{-1}\right)$ of Escherichia coli (ATCC 11229).

\begin{tabular}{|c|c|c|c|c|c|}
\hline \multirow{2}{*}{ Treatments } & \multicolumn{5}{|c|}{ Infectant doses (UFC.g ${ }^{-1}$ ) of Escherichia coli } \\
\hline & $10^{4}$ & $10^{5}$ & $10^{6}$ & $10^{7}$ & $10^{8}$ \\
\hline $\mathrm{HT}_{5 \%}$ & $3.5 \times 10^{3 \mathrm{aA}}$ & $5.5 \times 10^{3 \mathrm{abA}}$ & $5.9 \times 10^{4 \mathrm{bcA}}$ & $7.6 \times 10^{5 \mathrm{cdA}}$ & $\geq 1.0 \times 10^{6 \mathrm{dA}}$ \\
\hline $\mathrm{HT}_{10 \%}$ & $2.1 \times 10^{3 \mathrm{aA}}$ & $5.3 \times 10^{3 \mathrm{abA}}$ & $5.8 \times 10^{4 \mathrm{bcA}}$ & $2.2 \times 10^{5 \mathrm{cdA}}$ & $\geq 1.0 \times 10^{6 \mathrm{dA}}$ \\
\hline $\mathrm{HT}_{15 \%}$ & $1.6 \times 10^{3 \mathrm{aA}}$ & $6.3 \times 10^{3 \mathrm{abA}}$ & $7.1 \times 10^{4 \mathrm{bcA}}$ & $1.0 \times 10^{5 \mathrm{cdA}}$ & $6.4 \times 10^{5 \mathrm{dA}}$ \\
\hline $\mathrm{HT}_{20 \%}$ & $7.3 \times 10^{3 \mathrm{aA}}$ & $6.2 \times 10^{3 \mathrm{abA}}$ & $2.9 \times 10^{4 \mathrm{bcA}}$ & $1.4 \times 10^{4 \mathrm{cdA}}$ & $1.1 \times 10^{5 \mathrm{dA}}$ \\
\hline
\end{tabular}

HT (Hydroethanolic treatment: 5, 10, 15 and 20\%). UFC. $\mathrm{g}^{-1}$ values representing the antibacterial activity (three replicates on average). Different lowercase letters superscript in the same line indicate significant differences between the infective doses in relation to the same extract for the same bacterium in the non-parametric Kruskal-Wallis analysis, at $5 \%$ probability. Different capitalized letters superscript in the same column indicate significant difference between extracts in relation to the same infecting dose, for the same bacterium, by the non-parametric Kruskal-Wallis analysis, at $5 \%$ probability.

Table 2. The $\mathrm{pH}$ variation and counting of the mesophilic aerobic microorganisms (CFU.g ${ }^{-1}$ ) in meat model containing Hibiscus sabdariffa L. extracts.

\begin{tabular}{|c|c|c|c|c|c|c|c|}
\hline \multicolumn{8}{|c|}{ Period (days) } \\
\hline Tests & Treatments & 0 & 1 & 2 & 3 & 6 & 9 \\
\hline \multirow{2}{*}{$\mathrm{pH}$} & $\begin{array}{c}\text { T0 } \\
\text { (control) }\end{array}$ & $5.02^{\mathrm{aA}}$ & $5.22^{\mathrm{bA}}$ & $5.06^{\mathrm{aA}}$ & $5.04^{\mathrm{aA}}$ & $6.08^{\mathrm{cA}}$ & $7.10^{\mathrm{dA}}$ \\
\hline & $\mathrm{T} 2$ & $2.89^{\mathrm{aC}}$ & $2.95^{\mathrm{abc}}$ & $3.02^{\mathrm{bdC}}$ & $3.24^{\mathrm{cC}}$ & $3.24^{\mathrm{cC}}$ & $3.09^{\mathrm{dC}}$ \\
\hline \multirow{2}{*}{$\begin{array}{c}\text { Mesophilic } \\
\text { microorganisms } \\
\left(\text { CFU.g }{ }^{-1}\right)\end{array}$} & $\begin{array}{c}\text { T0 } \\
\text { (control) }\end{array}$ & $5.4 \times 10^{6 \mathrm{aA}}$ & $6.3 \times 10^{6 \mathrm{bA}}$ & $7.3 \times 10^{6 \mathrm{cA}}$ & $1.0 \times 10^{7 \mathrm{dA}}$ & $2.0 \times 10^{7 \mathrm{eA}}$ & $7.3 \times 10^{7 \mathrm{fA}}$ \\
\hline & $\mathrm{T} 2$ & $2.9 \times 10^{5 \mathrm{aA}}$ & $1.4 \times 10^{5 \mathrm{bA}}$ & $1.2 \times 10^{5 \mathrm{bA}}$ & $1.0 \times 10^{5 \mathrm{bB}}$ & $2.1 \times 10^{5 \mathrm{cBC}}$ & $2.3 \times 10^{5 \mathrm{cBC}}$ \\
\hline
\end{tabular}

T1 (80:20\% Hydroethanolic Extract) and T2 (70:30\% Hydroethanolic Extract). Values corresponding to the average of three replicates. Different lowercase letters superscript on the same line indicate significant differences between the treatment in relation to the different days for the non-parametric Kruskal-Wallis analysis at $5 \%$ probability. Different capitalized letters superscript in the same column indicate significant difference between treatments in relation to each day for non-parametric Kruskal-Wallis analysis, at $5 \%$ probability.

The treatment $\mathrm{HT}_{20 \%}$ presented a greater reduction in CFU.g ${ }^{-1}$ compared to the other treatments and to the highest infective doses. According to Barbosa et al. (2009), this can be explained by the fact that the higher the extract proportion, the greater the amount of antibacterial compounds. Agreeing with Hyldgaard et al. (2008), who suggest the use of essential oils at high concentrations in order to achieve sufficient antimicrobial activity for food preservation.

The $\mathrm{pH}$ variations in the experimental meat units is presented in Table 2. An increase in $\mathrm{pH}$ was noted in the treatment T0 (control) at the end of the storage period (day 9), similar to the results found by Arreguy Baptista et al. (2013) evaluating ground meat, with pHs greater than 6.5 , hence unfit for consumption. According to Jay (2005) the onset of meat degradation is accompanied by an increase in $\mathrm{pH}$.

According to the data presented here, after the use of extracts as meat additive, as the extract proportion in the meat model increases, the $\mathrm{pH}$ decreases. In the first reading (zero time), it was observed an immediate significant decrease $(\mathrm{p}<0.05)$, reaching $\mathrm{pH}$ values below 4.0 in treatments $\mathrm{T} 1$ and T2 compared to the T0 (control). This fact can be attributed to the acidity of the extracts used in different proportions, where, according to Juven et al. (1994) the antimicrobial potency of the components extracted from the vegetable also depends on the $\mathrm{pH}$. Thus remained constant during the 9 days of evaluation, affecting the multiplication of pathogenic and/or deteriorating microorganisms and can contribute to food preservation. This results takes into account that the growth of E. coli, which is an aerobic mesophilic bacteria, occurs at a $\mathrm{pH}$ range minimum of 4.2 to 4.3 , as reported by Silva (2005).

Table 2 presents that on day zero, all treatments had similar initial counts of mesophilic bacteria. Although Brazilian legislation (Brasil, 2001) does not establish tolerance limits for the group of aerobic mesophilic microorganisms, high populations of this group represents deficient hygienic-sanitary quality, often due to poor quality of the raw material allied to inadequate storage time and temperature. When these bacterial counts exceed $10^{6} \mathrm{CFU} \cdot \mathrm{g}^{-1}$ the product shelf life is compromised (Forsythe, 2013). From the $3^{\text {rd }}$ day of treatment, T2 had a significant antibacterial effect $(\mathrm{p}<0.05)$ compared to T0 (control), reducing to acceptable levels the initial count, remaining stable until the 9 th day of evaluation.

This decrease in the count of mesophilic bacteria is due to the bioactive compounds present in the natural additives and also the decrease of the $\mathrm{pH}$ during the storage. The composition of the plant extracts used depends on several factors such as the moment of plant harvest, variety, part of the plant and the extraction method used (Hyldgaard et al., 2008).

\section{Conclusions}

The hydroethanolic extracts of Hibiscus sabdariffa L. showed anti-Escherichia coli activity in the presence of refrigerated ground beef. Analyzing the $\mathrm{pH}$ and the count of aerobic mesophilic bacteria, the possibility of using as natural food additive of both hydroethanolic treatments is highlighted, obtaining a significant microbiological stability for the ground beef in the proportion of $30 \%$ of the extract. 


\section{References}

Arreguy Baptista, R. I. A., Moura, F. M. L., Fernandes, M. F. T. S., Santos, V. V. M., \& Fernandes, E. F. T. S. (2013). Aspectos qualitativos da carne moída comercializada na região metropolitana do Recife-PE. Acta Veterinaria Brasilica, 7(1), 38-47.

Association of Official Analytical Chemists - AOAC. (2012). Official methods of analysis of the Association of Official Analytical Chemists International (19th ed.). Washington: AOAC.

Barbosa, L. N., Rall, V. L., Fernandes, A. A., Ushimaru, P. I., Silva, P. I., \& Fernandes, A. Jr (2009). Essential oils against foodborne pathogens and spoilage bacteria in minced meat. Foodborne Pathogens and Disease, 6(6), 725-728. PMid:19580445. http://dx.doi.org/10.1089/ fpd.2009.0282.

Brasil. Agência Nacional de Vigilância Sanitária. (2000). Resolução (RDC) no 23, de 15 de Março de 2000. Dispõe sobre o Manual de Procedimentos Básicos para Registros e dispensa da obrigatoriedade de registro de produtos pertinentes à área de alimentos. Diário Oficial [da] República Federativa do Brasil.

Brasil. Agência Nacional de Vigilância Sanitária. (2001). Resolução (RDC) $\mathrm{n}^{\circ} 12$ de janeiro de 2001. Aprova o Regulamento Técnico sobre Padrões Microbiológicos para Alimentos. Diário Oficial [da] República Federativa do Brasil. Retrieved from http://www.anvisa. gov.br/legis/resol/12_01rdc.htm.

Brasil. Ministério da Agricultura, Pecuária e Abastecimento. (2003, September 18). Instrução Normativa (IN) nº 62 de 26 de agosto de 2003. Métodos analíticos oficiais para análises microbiológicas para controle de produtos de origem animal e água. Diário Oficial [da] República Federativa do Brasil, seção 1, p. 14.

Esteves, G. L., Duarte, M. C., \& Takeuchi, C. (2014). Sinopse de Hibiscus L. (Malvoideae, Malvaceae) do Estado de São Paulo, Brasil: espécies nativas e cultivadas ornamentais. Hoehnea, 41(4), 529-539. http:// dx.doi.org/10.1590/2236-8906-10/2014.

Farmacopéia Brasileira. (1987). (3. ed). São Paulo: Andrei Editora.

Forsythe, S. J. (2013). Microbiologia da segurança dos alimentos (2. ed.). Porto Alegre: Artmed.
Freire, M. F. I. (2004). Plantas medicinais: a importância do saber cultivar. Revista científica eletrônica agronomia, 3(5). Retrieved from http://faef.revista.inf.br/imagens_arquivos/arquivos_destaque/7uc emh9Yj4dcHPw_2013-4-26-12-10-36.pdf.

Germano, P. M. L., \& Germano, M. I. S. (2011). Higiene e vigilância sanitária de alimentos (4. ed.). São Paulo: Manole.

Hyldgaard, M., Mygind, T., \& Meyer, R. L. (2008). Essential oils in food preservation: mode of action, synergies, and interactions with food matrix components. Frontiers in Microbiology, (3), 1-24. PMid:22291693.

Jay, J. M. (2005). Microbiologia de alimentos (pp. 517-542, 6. ed.). Porto Alegre: The Art of Medication.

Juven, B. J., Kanner, J., Schved, F., \& Weisslowicz, H. (1994). Factors that interact with the antibacterial action of thyme essential oil and its active constituents. The Journal of Applied Bacteriology, 76(6), 626-631. PMid:8027009. http://dx.doi.org/10.1111/j.1365-2672.1994. tb01661.x.

Mariutti, Lilian R.B., Orlien, Vibeke, Bragagnolo, Neura, Skibsted, Leif H. (2008). Effect of sage and garlic on lipid oxidation in highpressure processed chicken meat. European Food Research and Techology, (227), 337-344.

Mehdi, A., Touba, E., Zarrin, S., \& Tahereh, E. (2013). An overview of the roselle plant with particular reference to its cultivation, diseases and usages. European Journal of Medicinal Plants, (3), 135-145.

Nascimento, M. V. D., Guedes, A. T. L., Silva, H. A., Santos, V. E. P., \& França Paz, M. C. (2014). Avaliação da qualidade microbiológica da carne moída fresca comercializada no mercado central em Campina Grande - PB. Revista Saúde \& Ciência On Line, 3(1), 56-68.

Nespolo, C. R., Oliveira, F. A., Pinto, F. S. T., \& Olivera, F. C. (2015). Práticas em Tecnologia de Alimentos. Porto Alegre: Artmed.

Silva, E. A. Jr. (2005). Manual de controle higiênico-sanitário em alimentos (6. ed.). São Paulo: Varela.

Simões, C. M. O., Schenkel, E. P., Gossmann, G., Mello, J. C. P., Mentz, L. A., \& Petrovick, P. R.(2001). Farmacognosia: da planta ao medicamento (3. ed.). Porto Alegre: UFRGS. 